\title{
AVIONICS TECHNICAL OPERATION SYSTEM AND SCIENTIFIC BASIS FOR ITS FORMATION
}

\author{
SERGEY V. KUZNETSOV ${ }^{1}$ \\ ${ }^{1}$ Moscow State Technical University of Civil Aviation, Moscow, Russia
}

\begin{abstract}
Avionics Technical Operation System (ATOS) is a set of objects and subjects of technical operation such as avionics itself as an object, personnel, carrying out procedures and organizing technical operation processes, as a subject, hardware and software for technical operation and maintenance and repair programs as well.

ATOS is subordinated to Aircraft Technical Operation System (A/C TOS), which determines its goal and restrictions. The quality of ATOS is characterized by a set of properties that determine its ability to meet the maximum economic efficiency of the needs of A/C TOS, while ensuring the required levels of avionics reliability and availability. Avionics Maintenance System, Avionics Repair System and Avionics Operation Test System are the systems of a lower level of hierarchy in relation to ATOS, which defines the goals and restrictions of these subsystems.

Based on the analysis of ATOS as an object of research, analysis of mathematical modeling as a research apparatus and the developed hierarchy of efficiency criteria for ATOS and the systems interacting with it, we formulate the overall task of the research as follows. On the set of parameters of ATOS, we have to find such parameter values that the system costs in process of technical operation reach the minimum when all the required tasks are fulfilled and all the restrictions on the system own parameters and indicators of its technical efficiency are met.

To solve the general task it is necessary to solve successfully a lot of tasks, formulated in this article. The theoretical results obtained during the research can serve as a scientific basis for solving practical problems of the formation and improvement of ATOS. Formation and improvement of ATOS is a long and laborious process, requiring the usage of the most advanced mathematical methods. Thus, mathematical modeling of ATOS should significantly reduce the costs of the system's formation, since it allows us to introduce certain adjustments in the early stages of its operation on the basis of available and constantly updated information.
\end{abstract}

Key words: mathematical models, processes and systems, technical operation, aircraft, avionics, on-board complexes, functional systems

\section{ANALYSIS AND FORMULATION OF THE RESEARCH PROBLEM. AVIONICS TECHNICAL OPERATION SYSTEM AS SUBJECT OF RESEARCH}

Structure of avionics technical operation system. Avionics Technical Operation System (ATOS) is a set of objects and subjects of technical operation such as avionics itself as an object, personnel, carrying out procedures and organizing technical operation processes, as a subject, hardware and software for technical operation and maintenance and repair programs as well. It is shown on Fig. 1.

Avionics, as an object of technical operation, is a complex of measuring, computing, control systems and information display systems intended for solving tasks of manual, automated, semiautomatic and automatic flying from take-off to landing and providing information to all the onboard and external consumers. Avionics can be analyzed at several levels of detail identified by the research objectives [1, 2].

Installed on board of the aircraft equipment is combined into avionics complexes (AC) or flight-navigation complexes (FNC), as a set of functional avionics systems (AS). Outside the aircraft avionics systems can be considered as a set of demountable units, devices and aggregates or Line Replaceable Units (LRU), which, in turn, can be considered as a set of constructive-functional modules or Line Replaceable Modules (ARM). 
Avionics complexes (AC) are combined by solving a variety of piloting and navigational tasks based on functional system integration and extensive intersystem connections.

Avionics functional systems (AS), as components of AC, are combined by solving some specific piloting and navigational tasks on the basis of structural-block complexation and wide interblock connections.

\begin{tabular}{|c|c|c|}
\hline $\begin{array}{c}\text { Avionics Technical Operation System (ATOS) } \\
\text { Avionics }\end{array}$ & Avionics ? & $\begin{array}{c}\text { echnical Operation System (ATOS) } \\
\text { Avionics }\end{array}$ \\
\hline & & \begin{tabular}{|l} 
Complexes (AC) \\
Systems (AS) \\
Line Replaceable Units (LRU) \\
Line Replaceable Modules (ARM) \\
Electrical and Radio Elements (ERE) \\
\end{tabular} \\
\hline & & Avionics Maintenance Facilities (AMF) \\
\hline & & $\begin{array}{l}\text { Aerodrome Facilities (AF) } \\
\begin{array}{l}\text { Avionics Test Equipment (ATE) and Re- } \\
\text { covery Facilities (ARF) }\end{array} \\
\text { Spare Parts, Tools and Accessories (SPTA) } \\
\text { Consumables }\end{array}$ \\
\hline & & $\begin{array}{c}\text { Aircraft Maintenance and Repair Pro- } \\
\text { gram (AMRP) }\end{array}$ \\
\hline & & \begin{tabular}{|l|} 
Methods of Technical Operation \\
Strategies of Maintenance \\
Maintenance and Repair Periodicity \\
Maintenance and Repair Volumes and \\
Technologies
\end{tabular} \\
\hline & & Crew and Maintenance Personnel (CMP) \\
\hline & & $\begin{array}{l}\text { Crew Personnel } \\
\text { Aircraft Line Maintenance Engineers } \\
\text { Aircraft Base Maintenance Engineers } \\
\text { Components Maintenance Engineers } \\
\text { Overhaul and Repair Engineers } \\
\text { Engineering Centers Personnel }\end{array}$ \\
\hline
\end{tabular}

Fig. 1. Structure of avionics technical operation system

Avionics Line Replaceable Units (LRU), as parts of AS, are combined with the solution of some particular tasks of a certain function of the system within the framework of a construct providing an autonomous installation of LRU on board and its disassembly from the aircraft.

Avionics Line Replaceable Modules (LRM), as components of LRUs, are designed to solve some particular tasks of a certain function of the LRU within the framework of the construction, which ensures the installation of the LRM in the LRU and its disassembly from the unit.

Finally, Electrical and Radio Elements (ERE), as constituent parts of LRM, are elementary constructively finished units that ensure the functioning of LRM and do not involve non-destructive installations and dismantling works. 
Avionics Maintenance Facilities (AMF) include Aerodrome Facilities (AF), Test and Avionics Recovery Facilities (TARF), Spare Tools and Accessories (STA) and Consumables intended to solve the tasks of technical operation of all the avionics objects installed on the board of aircraft: avionics complexes, systems, LRU, LRM and ERE.

Aerodrome Facilities provide avionics electrical and hydraulic power on the ground and are the parts of general Aerodrome Facilities for aircrafts maintenance.

Avionics Test Equipment (ATE) include on-board Built-in-Test Equipment (BITE), on-board Registration and on-ground Decryption Equipment (RDE), as well as Control and Testing Equipment (CTE) for Line Maintenance.

Avionics Recovery Facilities (ARF) are LRU onboard and LRM or ERE in laboratories for substitutions of LRU, LRM and ERE which are in fail. Spare Parts, Tools and Accessories (STA) and Consumables are also used for maintenance.

Aircraft Maintenance and Repair Program (AMRP) includes separate chapters for avionics maintenance. There are Methods of technical operation for every LRU, Strategies of Maintenance for every AS, Maintenance and Repair Periodicity for AC and AS, Maintenance and Repair Volumes and Technologies for AC, AS and LRU.

Crew and Maintenance Personnel (CMP) carry out procedures and organize processes of technical operation in accordance with the requirements of operating manuals and regulatory documents in order to ensure flight safety and high cost efficiency. It includes Crew Personnel - pilots, providing preflight tests and using of avionics in flight; Aircraft Line Maintenance Engineers - mechanics, technicians and engineers providing avionics Line Maintenance; Aircraft Base Maintenance Engineers mechanics, technicians and engineers providing avionics Base Maintenance in hangars; Components Maintenance Engineers - technicians and engineers providing Maintenance of avionics LRU in laboratories; Overhaul and Repair Engineers - mechanics, technicians and engineers providing avionics Overhaul and Repair in external organizations; Engineering Centers Personnel - technicians and engineers working with maintenance documentation and providing help for all the maintenance personnel who need it.

Structure of avionics technical operation processes and its states. Quality of ATOS manifests itself in processes of technical operation (PTO) - sets of operating usage processes in flight, operational control, maintenance, recover and repair (Fig. 2).

The use of avionics for its intended purpose - Operating Usage in Flight, - includes its work in preparatory and unloaded modes that provide availability for immediate use, and work in the major loaded modes that ensure the performance of functional tasks. The use of avionics for its intended purpose leads to failures and malfunctions that are detected in the operational control processes: Build-in-Test in Flight, Post-flight, Pre-flight Tests and Tests of dismantled equipment (LRU).

Operational Control Test is a part of Maintenance which include Line, Basic, Season, Special and Storage Maintenance. Another component of maintenance in an Aircraft Maintenance Organization (AMO) is recovery - emergency and preventive. Repair includes three types of processes: Planned Current and Capital, Non-planned on-Condition.

Avionics technical operation processes as processes of avionics technical states changing occur in time under the influence of many factors that have as random as non-random nature. These include the occurrence of failures, defects and malfunctions, quality of maintenance, trustworthiness of test, the provision of spare parts, etc. (Fig. 3).

The Set of Avionics Operating States includes On-board in Flight (for avionics complexes and systems) states, On-board on Ground (for avionics complexes and systems) states, Dismantled from Board (for LRUs) states. Depending on the type of technical condition we can distinguish Perfect and Up State, Imperfect but Up State, Imperfect and Down State of Avionics. Depending on the test results we can distinguish Detected Perfect and Up State, False Imperfect and Down State, Undetected Imperfect and Down State, Detected Imperfect and Down State. 
Transitions of the operation processes from state to state occur both at random and at deterministic instants of time. Such transitions are generated by event flows (for example, failures, recoveries, test procedures, etc.).

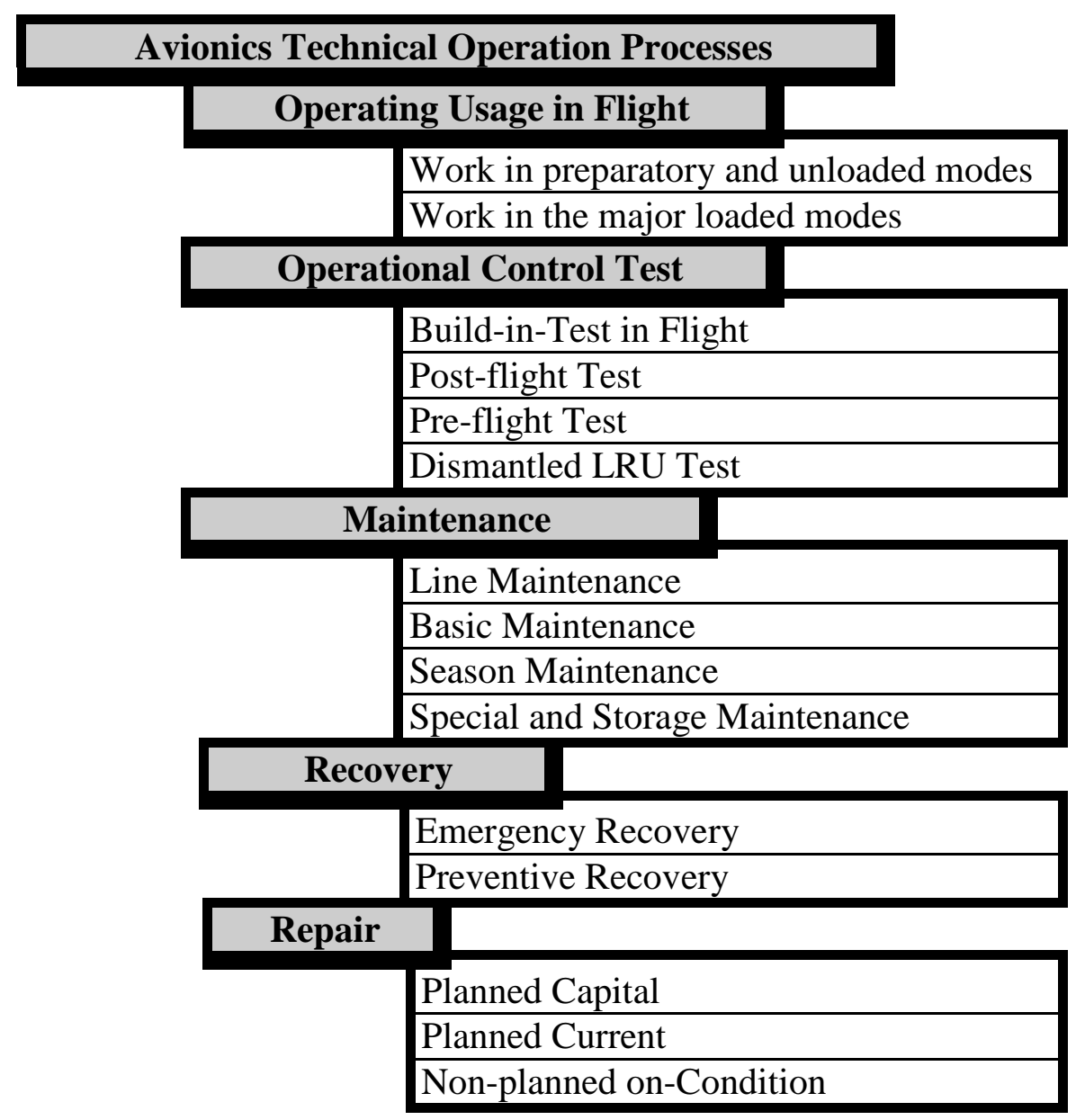

Fig. 2. Structure of avionics technical operation processes

That is why an avionics technical operation process can be considered as a random process, which is determined on the set of operating states by the probabilistic characteristics of the transitions. This circumstance allows us to solve the problems of avionics technical operation process analyzing with the help of the well-developed apparatus of the theory of random processes.

Avionics technical operation process in its essence is a controlled process. The possibility of intervention in this process has both an objective deterministic nature, conditioned by the operation manual and the maintenance and repair program, as well as the subjective random nature caused by the unlawful or erroneous actions of the personnel.

That is, an avionics technical operation process can be regarded as a controlled random process determined by a set of control actions and external perturbations with probability characteristics. This allows us to solve the problems of process optimization and the synthesis of an avionics technical operation system using the apparatus of the theory of controlled random processes and the theory of automatic control.

Hierarchy of ATOS. The Aircraft Technical Operation System (A/C TOS) is a system of a higher level of hierarchy in relation to Avionics Technical Operation System ATOS (Fig. 4). The quality of A/C TOS is characterized by a set of properties that determine its ability to meet the needs of the Aviation Transport System (ATS) with maximum economic 
efficiency while ensuring the required levels of flight safety, flight regularity and aircraft availability [3, 4].

Set of Avionics Operating States

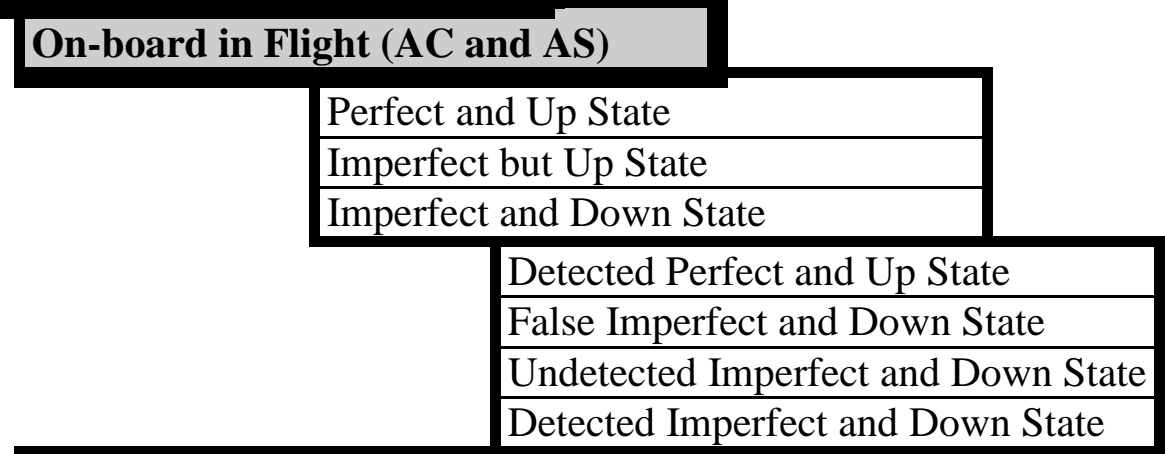

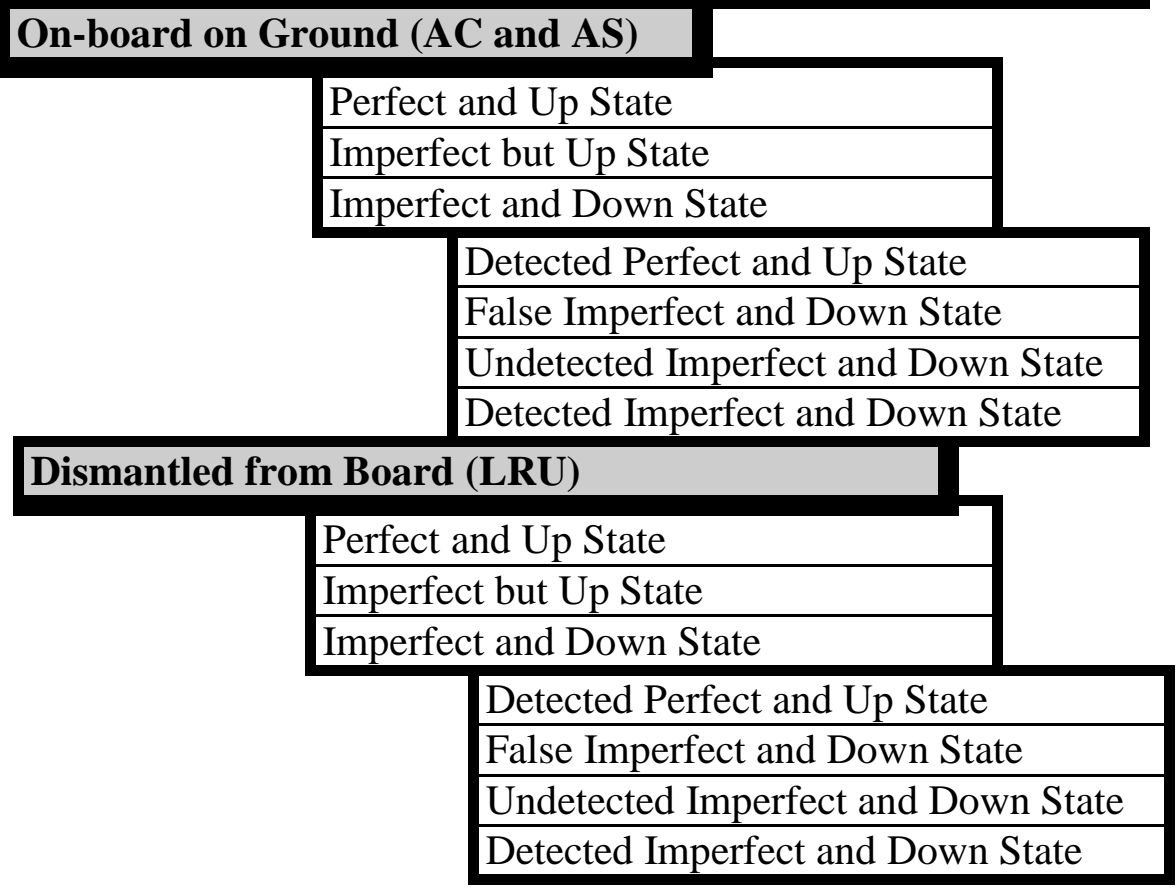

Fig. 3. Structure of avionics operating states set

ATOS is subordinated to A/C TOS, which determines its goal and restrictions. The quality of ATOS is characterized by a set of properties that determine its ability to meet the maximum economic efficiency of the needs of A/C TOS, while ensuring the required levels of avionics dependability and availability. There are also Airframe Technical Operation System (AfTOS), Power Plant Technical Operation System (PPTOS), Mechanical and Electrical Equipment Technical Operation System (METOS) with their own goals and restrictions.

Avionics Maintenance System, Avionics Repair System and Avionics Operation Test System are the systems of a lower level of hierarchy in relation to ATOS, which defines the goals and restrictions of these subsystems.

Thus, ATOS has all the features inherent in complex technical systems, namely: the hierarchical branched structure, the subordination of goals and restrictions, wide interrelations in the process of functioning. This allows us to conclude that the formation and improvement of ATOS should be carried out on the basis of Systems Analysis of the processes occurring in it using modern mathematical methods of the theory of Complex Systems [5, 6, 7].

In accordance with the hierarchy of goals and restrictions of systems interacting with ATOS we can suggest the hierarchy of the criteria for the effectiveness of A/C TOS and ATOS. To do it, it is 
necessary to formalize the tasks they solve, their characterizing parameters, as well as the processes taking place in them.

\begin{tabular}{|c|l|}
\hline \multicolumn{2}{|c|}{ Aircraft Technical Operation System (A/C TOS) } \\
\hline Goal & $\begin{array}{l}\text { Meeting the needs of the Aviation Transport System (ATS) with the } \\
\text { maximum economic efficiency }\end{array}$ \\
\hline Restrictions & Required levels of flight safety, flight regularity and aircraft availability \\
\hline \multicolumn{1}{|c|}{ Airframe Technical Operation System } \\
\hline Goal & $\begin{array}{l}\text { Mecher plant Technical Operation System } \\
\text { Avionics Technical Operation System the needs of A/C TOS with the maximum economic } \\
\text { efficiency }\end{array}$ \\
\hline Restrictions & Required levels of avionics dependability and availability \\
\hline & Avionics Maintenance System \\
\hline Goal & $\begin{array}{l}\text { Avionics Operation Test System (AOTS) } \\
\text { ciency the needs of ATOS with the maximum economic effi- }\end{array}$ \\
\hline Restrictions & Required levels of avionics test trustworthiness \\
\hline
\end{tabular}

Fig. 4. Structure and hierarchy of goals and restrictions of systems interacting with ATOS

Let $\Omega_{T O S}^{A C}$ - to be the set of tasks solved by A/C TOS. The system of a higher level of the hierarchy - the air transport system (ATC), imposes a number of required tasks $\left(\Omega_{T O S}^{A C}\right) *$ for the implementation of $\mathrm{A} / \mathrm{C}$ TOS.

Let $\Gamma_{T O S}^{A C}=\left\{\gamma_{T O S}^{A C}(j)\right\}$ - to be the set of parameters of A/C TOS determined by its structure, connections, resources, and characteristics. The set of restrictions on the parameters of A/C TOS $\left(\Gamma_{T O S}^{A C}\right)^{*}=\left[\left\{\gamma_{T O S}^{A C}(j)\right\}^{*}\right]$ defines the limits of the parameter change $\Gamma_{T O S}^{A C}$, based on the conservatism of the structures and connections, limited resources and maximum attainability of A/C TOS characteristics.

Process of technical operation $\xi_{O S}^{A C}\left(\mathrm{t}, \Gamma_{T O S}^{A C}\right)$ as a function of time $\mathrm{t}$ and of the set of parameters $\Gamma_{T O S}^{A C}$ determines the efficiency of A/C TOS , which proves itself in economic and technical indicators. Let $C_{T O S}^{A C}$ - to be the indicator of economic efficiency of A/C TOS, determined in the process of technical operation, for example, operating costs.

The set of values of technical performance indicators of A/C TOS will be denoted by $R_{T O S}^{A C}=\left\{r_{T O S}^{A C}(l)\right\}$.

Each indicator $r_{T O S}^{A C}(l)=r_{O S}^{A C}\left(\mathrm{t}, \Gamma_{T O S}^{A C}\right)$ is a function of time $\mathrm{t}$ and of the set of parameters $\Gamma_{T O S}^{A C}$. ATS as hierarchy higher-level system presents the required values of the set of technical efficiency indicators $\left(R_{T O S}^{A C}\right)^{*}=\left[\left\{r_{T O S}^{A C}(l)\right\}^{*}\right]$.

Then the criterion of the effectiveness of A/C TOS is the set of objective function and restrictions

$$
\begin{gathered}
\min \left[C_{T O S}^{A C}\left\{\xi_{O S}^{A C}\left(\mathrm{t}, \Gamma_{T O S}^{A C}\right)\right\}\right], \\
\gamma_{T O S}^{\mathrm{AC}}(j) \in \Gamma_{T O S}^{A C}(j) \\
\left(\Omega_{T O S}^{A C}\right)^{*}-\Omega_{T O S}^{A C}=\emptyset,\left(\Omega_{T O S}^{A C}\right)^{*} \in\left(\Omega_{A T S}\right)^{*},
\end{gathered}
$$




$$
\begin{gathered}
\gamma_{T O S}^{A C}(j) \geq \leq\left\{\gamma_{T O S}^{A C}(j)\right\}^{*}, \gamma_{T O S}^{A C}(j) \in \Gamma_{T O S}^{A C} \\
r_{T O S}^{A C}(l) \geq \leq\left\{r_{T O S}^{A C}(l)\right\}^{*}, r_{T O S}^{A C}(l) \in R_{T O S}^{A C},\left(R_{T O S}^{A C}\right) * \in R_{T O S}^{*} .
\end{gathered}
$$

That is, the criterion for the effectiveness of A/C TOS is to achieve the minimum value of the economic efficiency index at the given set of system parameters in the process of technical operation, provided all the required by ATS tasks are fulfilled, and all the restrictions on the system parameters and indicators of its technical efficiency are met.

ATOS solves a set of tasks $\Omega_{\text {TOS }}^{A}$. A/C TOS as a system of higher level of the hierarchy imposes a required set of tasks for the implementation $\left(\Omega_{T O S}^{A C}\right) *$, and $\left(\Omega_{T O S}^{A}\right) * \in\left(\Omega_{T O S}^{A C}\right) *$.

Let $\Gamma_{T O S}^{A}=\left\{\gamma_{T O S}^{A}(j)\right\}$ - to be the set of parameters of ATOS determined by its structure, connections, resources, and characteristics. The set of restrictions on the parameters of $\operatorname{ATOS}\left(\Gamma_{T O S}^{A}\right)^{*}=\left[\left\{\gamma_{T O S}^{A}(j)\right\}^{*}\right]$ defines the limits of the parameter change $\Gamma_{T O S}^{A}$, based on the conservatism of the structures and connections, limited resources and maximum attainability of ATOS characteristics.

Process of technical operation $\xi_{O S}^{A}\left(\mathrm{t}, \Gamma_{T O S}^{A}\right)$ is embedded in the process of technical operation $\xi_{O S}^{A C}\left(\mathrm{t}, \Gamma_{T O S}^{A C}\right)$. It is also a function of time $\mathrm{t}$ and of the set of parameters $\Gamma_{T O S}^{A}$.

The economic efficiency of ATOS is characterized by operating costs $C_{T O S}^{A}$, determined in the process of technical operation $\xi_{O S}^{A}\left(\mathrm{t}, \Gamma_{T O S}^{A}\right)$.

The technical effectiveness of ATOS is characterized by a set of indicators $R_{T O S}^{A}=\left\{r_{T O S}^{A}(l)\right\}$, with each indicator $r_{T O S}^{A}(l)=r_{O S}^{A}\left(\mathrm{t}, \Gamma_{T O S}^{A}\right)$ to be a function of time $\mathrm{t}$ and a set of parameters $\Gamma_{T O S}^{A}$. $\mathrm{A} / \mathrm{C}$ TOS as hierarchy higher-level system imposes the required values of the set of technical efficiency indicators $\left(R_{T O S}^{A}\right)^{*}=\left[\left\{r_{T O S}^{A}(l)\right\}^{*}\right]$.

That is, the criterion for the effectiveness of ATOS is to achieve the minimum value of the economic efficiency index at the given set of system parameters in the process of technical operation, provided all the required by A/C TOS tasks are fulfilled, and all the restrictions on the system parameters and indicators of its technical efficiency are met.

$$
\begin{gathered}
\min \left[C_{T O S}^{A}\left\{\xi_{O S}^{A}\left(\mathrm{t}, \Gamma_{T O S}^{A}\right)\right\}\right], \\
\gamma_{T O S}^{\mathrm{A}}(j) \in \Gamma_{T O S}^{A}(j) \\
\left(\Omega_{T O S}^{A}\right)^{*}-\Omega_{T O S}^{A}=\emptyset,\left(\Omega_{T O S}^{A}\right)^{*} \in\left(\Omega_{A T S}^{A C}\right)^{*}, \\
\gamma_{T O S}^{A}(j) \geq \leq\left\{\gamma_{T O S}^{A}(j)\right\}^{*}, \gamma_{T O S}^{A}(j) \in \Gamma_{T O S}^{A}, \\
r_{T O S}^{A}(l) \geq \leq\left\{r_{T O S}^{A}(l)\right\}^{*}, r_{T O S}^{A}(l) \in R_{T O S}^{A},\left(R_{T O S}^{A}\right)^{*} \in R_{T O S}^{*} .
\end{gathered}
$$

Thus, the hierarchy of criteria for the effectiveness of ATOS and A/C TOS has been constructed. In the same way, the hierarchy of criteria for the effectiveness of ATOS and Avionics Operation Test System (AOTS) is constructed [8, 9, 10].

Statement of the general task of the research work and its decomposition into compound tasks. Based on the analysis of ATOS as an object of research, analysis of mathematical modeling as a research apparatus and the developed hierarchy of efficiency criteria for ATOS and the systems interacting with it, we formulate the overall task of the research as follows.

On the set of parameters of the Avionics Technical Operation System (ATOS), we have to find the parameter values such that the system costs in process of technical operation reach the minimum when all the required tasks are fulfilled and all the restrictions on the system own parameters and indicators of its technical efficiency are met. 
To solve the general task it is necessary to solve successively the following tasks:

- analyze avionics process of technical operation (as for existing avionics, as for new designed avionics) on the basis of operational statistics using modern statistical methods for the subsequent validation of mathematical models;

- develop mathematical models of the characteristics of process of technical operation, for which to modify the traditional methods of determining the failure flow parameter and the failure rate function;

- develop mathematical models of process of avionics technical operation on the basis of the results of analysis of operational statistics and to carry out appropriate revision of the mathematical apparatus taking into account the features of models;

- develop mathematical models for optimization process of avionics technical operation with deepening of the capabilities of the mathematical apparatus and carry out optimization;

- develop mathematical models for the synthesis of Avionics Technical Operation System with the deepening of the capabilities of the mathematical apparatus and carry out synthesis.

The theoretical results obtained during the research can serve as a scientific basis for solving practical problems of the formation and improvement of Avionics Technical Operation System.

\section{CONCLUSION}

Analytical and simulation modeling of ATOS in processes of technical operation. Formation and improvement of ATOS is a long and laborious process, requiring the usage of the most advanced mathematical methods. This is explained by the fact that, firstly, ATOS are complex systems, for the analysis of which until now no general mathematical and engineering methods have been created.

Secondly, the quality of ATOS shows itself over fairly long time interval, often spanning several years. The required quality is achieved only at the stationary stage of the technical operation process. Control influences on the system are very limited due to its conservatism. In addition, the system itself has a high cost, and any changes in it can affect the safety of flights.

Thus, mathematical modeling of ATOS should significantly reduce the costs of the system's formation, since it allows us to introduce certain adjustments in the early stages of its operation on the basis of available and constantly updated information.

\section{REFERENCES}

1. Fedosov E.A., Kos'yanchuk V.V., Sel'vesyuk N.I. Integrirovannaya modul'naya avionika [Integrated Modular Avionics]. Radioelektronnyye tekhnologii [Radio-electronic technologies], 2015, no. 1, pp. 66-71. (in Russian)

2. Kucheryavyy A.A. Avionika [Avionics]. SPb., Lan', 2016, 460 pp. (in Russian)

3. Smirnov N.N., Chinyuchin Yu.M. Osnovy teorii tekhnicheskoy ekspluatatsii letatel'nykh apparatov [Fundamentals of the theory of technical operation of aircraft]. M., MGTU GA, Insoft. [MSTUCA, Insoft], 2015, 600 p. (in Russian)

4. Itskovich A.A., Kabkov P.K. Veroyatnostno-statisticheskiye modeli ekspluatatsii LA [Probabilistic-statistical models of operation]. M., MGTU GA [MSTUCA], 2009, 144 p.

5. Mesarovich M., Takakhara Ya. Obshchaya teoriya sistem: matematicheskiye osnovy [General theory of systems: mathematical foundations]. M., Mir, 1978, 512 p. (in Russian)

6. Hinrichsen D., Pritchard A.J. Mathematical Systems Theory I, 2005, 804 p.

7. Rogers E., Galkowski K., Owens D.H. Control Systems Theory and Applications for Linear Repetitive Processes, 2007, 600 p.

8. Kuznetsov S.V. Matematicheskiye modeli protsessov i sistem tekhnicheskoy ekspluatatsii avioniki kak markovskiye tsepi [Mathematical models of processes and systems of avionic technical 
operation as Markov chains]. Nauchnyj Vestnik MGTU GA [Scientific Bulletin of the MSTUCA], 2014, no. 201, pp. 56-64. (in Russian)

9. Kuznetsov S.V. Matematicheskiye modeli protsessov i sistem tekhnicheskoy ekspluatatsii avioniki kak markovskiye i polumarkovskiye protsessy [Mathematical models of processes and systems of avionic technical operation as Markov and Semimarkov processes]. Nauchnyj Vestnik MGTU GA [Scientific Bulletin of the MSTUCA], 2015, no. 213, pp. 28-33. (in Russian)

10. Kuznetsov S.V. Matematicheskiye modeli protsessov i sistem tekhnicheskoy ekspluatatsii bortovykh kompleksov i funktsional'nykh sistem avioniki [Mathematical models of processes and systems of technical operation for onboard complexes and functional systems of avionics]. Nauchnyj Vestnik MGTU GA [Scientific Bulletin of the MSTUCA], 2017, vol. 20, no. 01, pp. 132-140. (in Russian)

\title{
INFORMATION ABOUT THE AUTHOR
}

Sergey V. Kuznetsov, Doctor of Technical Sciences, Professor, Head of Chair of Aircraft Electrical Systems and Avionics Technical Operation of Moscow State Technical University of Civil Aviation,s.kuznetsov@mstuca.aero.

\section{СИСТЕМА ТЕХНИЧЕСКОЙ ЭКСПЛУАТАЦИИ АВИОНИКИ И НАУЧНЫЕ ОСНОВЫ ЕЕ ФОРМИРОВАНИЯ}

\author{
С.В. Кузнецов 1 \\ ${ }^{1}$ Московский государственный технический университет гражданской авиации, \\ 2. Москва, Россия
}

Система технической эксплуатации авионики (СТЭА) - это совокупность объектов и средств технической эксплуатации, программ технического обслуживания и ремонта, а также персонала, осуществляющего процедуры и организующего процессы технической эксплуатации авионики.

СТЭА подчинена системе технической эксплуатации воздушного судна (СТЭВС), которая определяет ее цель и ограничения. Качество СТЭА характеризуется совокупностью свойств, определяющих ее способность удовлетворять с максимальной экономической эффективностью потребности СТЭВС, обеспечивая при этом требуемые уровни надежности и готовности авионики к эксплуатации. По отношению к СТЭА системами более низкого уровня иерархии являются системы технического обслуживания, ремонта, эксплуатационного контроля. СТЭА определяет цели и ограничения этих систем.

На основании анализа СТЭА как объекта исследования, анализа математического моделирования как аппарата исследования и разработанной иерархии критериев эффективности СТЭА и взаимодействующих с ней систем, общая задача научно-исследовательской работы сформулирована следующим образом. На заданном множестве параметров СТЭА определить значения параметров такие, чтобы затраты системы в процессе технической эксплуатации достигали минимума при выполнении всех требуемых задач и соблюдении всех ограничений на собственные параметры системы и показатели ее технической эффективности.

Для решения общей задачи необходимо последовательно решить целый ряд задач, сформулированных в статье. Полученные при исследовании теоретические результаты могут служить научной основой для решения практических задач формирования и совершенствования СТЭА. Формирование и совершенствование СТЭА - процесс длительный и трудоемкий, требующий привлечения самых совершенных математических методов. Таким образом, математическое моделирование СТЭА должно существенно снизить издержки формирования системы, так как позволяет на ранних этапах ее функционирования вводить определенные коррективы на основе располагаемой и постоянно обновляемой информации.

Ключевые слова: математические модели, процессы и системы, техническая эксплуатация, воздушное судно, авионика, бортовые комплексы, функциональные системы.

\section{СПИСОК ЛИТЕРАТУРЫ}

1. Федосов Е.А., Косьянчук В.В., Сельвесюк Н.И. Интегрированная модульная авионика // Радиоэлектронные технологии. 2015. № 1. С. 66-71. 
2. Кучерявый А.А. Авионика. СПб.: Лань, 2016. 460 с.

3. Смирнов Н.Н., Чинючин Ю.М. Основы теории технической эксплуатации летательных аппаратов: учебник. М.: МГТУ ГА, Инсофт, 2015. 600 с.

4. Ицкович А.А., Кабков П.К. Вероятностно-статистические модели эксплуатации ЛА. М.: МГТУ ГА, 2009. 144 с.

5. Месарович М., Такахара Я. Общая теория систем: математические основы. М.: Мир, 1978. $512 \mathrm{c.}$

6. Hinrichsen D., Pritchard A.J. Mathematical Systems Theory I. 2005. 804 p.

7. Rogers E., Galkowski K., Owens D.H. Control Systems Theory and Applications for Linear Repetitive Processes. 2007. 600 p.

8. Кузнецов С.В. Математические модели процессов и систем технической эксплуатации авионики как марковские цепи // Научный Вестник МГТУ ГА. 2014. № 201. С. 56-64.

9. Кузнецов С.В. Математические модели процессов и систем технической эксплуатации авионики как марковские и полумарковские процессы // Научный Вестник МГТУ ГА. 2015. № 213. С. 28-33.

10. Кузнецов С.В. Математические модели процессов и систем технической эксплуатации бортовых комплексов и функциональных систем авионики // Научный Вестник МГТУ ГА. 2017. Том 20. № 01. С. 132-140.

\section{СВЕДЕНИЯ ОБ АВТОРЕ}

Кузнецов Сергей Викторович, профессор, доктор технических наук, заведующий кафедрой технической эксплуатации авиационных электросистем и пилотажно-навигационных комплексов МГТУ ГА, s.kuznetsov@mstuca.aero. 